\title{
Genomic and transcriptomic comparison between Staphylococcus aureus strains associated with high and low within herd prevalence of intra-mammary infection
}

\author{
E. Capra ${ }^{1 *+}$, P. Cremonesi ${ }^{1 \dagger}$, A. Pietrelli ${ }^{2,6}$, S. Puccio ${ }^{2,5}$, M. Luini $^{3}$, A. Stella ${ }^{1,4}$ and B. Castiglioni ${ }^{1}$
}

\begin{abstract}
Background: Staphylococcus aureus (Staph. aureus) is one of the major pathogens causing mastitis in dairy ruminants worldwide. The chronic nature of Staph. aureus infection enhances the contagiousness risk and diffusion in herds. In order to identify the factors involved in intra-mammary infection (IMI) and diffusion in dairy cows, we investigated the molecular characteristics of two groups of Staph. aureus strains belonging to ST8 and ST398, differing in clinical properties, through comparison of whole genome and whole transcriptome sequencing.

Results: The two groups of strains, one originated from high IMI prevalence herds and the other from low IMI prevalence herds, present a peculiar set of genes and polymorphisms related to phenotypic features, such as bacterial invasion of mammary epithelial cells and host adaptation. Transcriptomic analysis supports the high propensity of ST8 strain to chronicity of infection and to a higher potential cytotoxicity.

Conclusions: Our data are consistent with the invasiveness and host adaptation feature for the strains GTB/ST8 associated to high within-herd prevalence of mastitis. Variation in genes coding for surface exposed proteins and those associated to virulence and defence could constitute good targets for further research.
\end{abstract}

Keywords: Staphylococcus aureus, Mastitis, Virulence, Genome, Transcriptome, Next generation sequencing

\section{Background}

Mastitis is reported as one of the most important diseases for dairy cattle on the basis of great economical losses caused by affecting animal welfare and milk production costs [1]. Staphylococcus aureus is one of the major cause of intra-mammary infection (IMI) in ruminants worldwide, causing mastitis with diverse degrees of severity. In dairy cows, Staph. aureus IMI is almost always subclinical, thus leading to an increasing risk of contagion and diffusion in the herds [2]. The molecular pattern of Staph. aureus isolates in diverse farm animal forms distinct genetic clusters differing in the presence of pathogenic factors that increase their invasiveness, even in the presence of a stronger inflammatory

\footnotetext{
* Correspondence: e.capra@ibba.cnr.it

${ }^{\dagger}$ Equal contributors

'Istituto di Biologia e Biotecnologia Agraria, CNR, via Einstein, 26900 Lodi, Italy

Full list of author information is available at the end of the article
}

response [3]. In a recent study [4], subtypes of Staph. aureus were associated with high within-herd IMI, compared to other different subtypes that were associated with low within-herd prevalence. This study and previous data $[5,6]$ confirmed that particular gene patterns, virulence profiles and specific genotypes could be associated with diverse clinical outcomes. More recently, two large European studies [7, 8], demonstrated that the Repetitive-Sequence PCR RS-PCR genotype B (GTB), belonging to the Sequence Type ST8 $[9,10]$, a high contagious and diffusive Staph. aureus involved in bovine IMI, was the most frequently detected in several European countries (Austria, Belgium, France, Germany, Italy, Switzerland). Conversely, the RS-PCR genotype S (GTS), belonging to ST398 $[11,12]$, was one of the rare genotypes found in bovine milk samples. The ST8 was previously found in both human and dairy cow mastitis [4], suggesting that, after a human-to-cow host jump, a new bovine 
adaptation took place. At the same time, the ST398 showed a host transition from human to animal reservoir, becoming the most widely disseminated clonal complex in bovine species and in the milk samples collected in herds with low prevalence of IMI [13-15].

The existence of subtypes of Staph. aureus differing in pathogenic properties emphasizes the need to well define strain characteristics, in order to monitor bacteria dissemination and find potential relevant targets related to their contagiousness. In recent years the advent of next generation sequencing (NGS) technologies has improved the estimate of the correlation of virulence phenotype to genome structure, providing a more detailed picture of gene patterns involved into staphylococcal pathogenesis. High-throughput whole-genome sequencing of Staph. aureus was prevalently used to monitor outbreaks in hospitals $[16,17]$, to evaluate strains transitioning from carrier to invasive status [18] and to understand aspects of pathogen biology in detailed epidemiological studies in human [19-21]. In livestock community, the molecular basis of virulence in Staph. aureus mastitis was investigated by using an integrated approach that includes NGS, microarray and proteomic data [22] providing the first high-resolution comparison between gene content and gene expression in two Staph. aureus strains. More recently, Peton and coworkers [23] described a fine-tuned characterization of Staph. aureus Newbond 305, a strain belonging to ST115 and associated to bovine mastitis, by genomic and proteomic comparison with the reference strain RF122. Gene expression analysis by microarray techniques has provided, also, information about global transcript changes [24, 25] or molecular basis of virulence [26] in Staph. aureus. Moreover, RNA-seq was recently used to study (i) the gene expression in different Staph. aureus strains [27, 28], (ii) the role of anti-sense transcription [29] and (iii) the identification of small non-coding RNAs [30].

To gain further insight into Staph. aureus features, the aim of this work was the characterization of two groups of Staph. aureus strains differing in their clinical outcome. Each strain was comprehensively studied by comparative genomic and transcriptomic analysis in order to identify staphylococcal factors that can be associated with strain virulence and bacterial diffusion in the herd.

\section{Methods}

\section{Bacterial strains}

Six bacterial strains, originally isolated from subclinical cases of bovine IMI in six different Holstein herds (A-F, Table 1) located in Lombardy region in the northern of Italy, were used in this study. The average size of the herds was 106 milking cows (range 38 to 285 cows). Milk samples were collected aseptically. Samples were kept at $4{ }^{\circ} \mathrm{C}$ and bacteriological assays were performed within $48 \mathrm{~h}$. Isolates were classified into two groups: Staph. aureus belonging to low within-herd mastitis prevalence (herds A, B, C) or high within-herd mastitis prevalence (herds D, E, F). As described in Table 1, and reported by Cremonesi and colleagues [4], Staph. aureus isolates had been previously characterized by RS-PCR, Multi Locus Sequence Type (MLST) [31], for presence of mecA gene and for different virulence genes. The strains collected in three different herds with low mastitis prevalence (between 2 and $4 \%$ ) were identified by RS-PCR as genotype S (GTS) and by MLST as ST398 (hereinafter referred as GTS/ ST398). Two out of three were positive for mecA gene. The strains isolated from three herds with high IMI prevalence (between 49 and 62\%) were identified by RS-PCR as genotype B (GTB) and ST8 (hereinafter referred as GTB/ ST8) and none of them harboured the mecA gene coding for methicillin resistance.

Table 1 Characteristics of the bacterial strains used in this study

\begin{tabular}{|c|c|c|c|c|c|c|}
\hline & Herd & IMI prevalence & MLST & RS-PCR & mecA & Virulence profile* \\
\hline \multicolumn{7}{|l|}{ GTS/ST398 } \\
\hline Strain 1 & A & $4 \%$ & ST398 & GTS & + & lukE, cna, fmtb, scn, chp, lukM \\
\hline Strain 2 & B & $2 \%$ & ST398 & GTS & - & clfA, lukE, cna, fmtb, scn, chp, lukM \\
\hline Strain 3 & C & $2 \%$ & ST398 & GTS & + & clfA, lukE, cna, fmtb, lukM \\
\hline \multicolumn{7}{|l|}{ GTB/ST8 } \\
\hline Strain 1 & D & $49 \%$ & ST8 & GTB & - & clfA, lukE, cna, sea, sed, sej, fmtb, scn, chp \\
\hline Strain 2 & E & $54 \%$ & ST8 & GTB & - & clfA, lukE, cna, sea, sed, sej, fmtb, scn, chp \\
\hline Strain 3 & $\mathrm{~F}$ & $62 \%$ & ST8 & GTB & - & clfA, lukE, cna, sed, sej, seg, sei, fmtb, chp \\
\hline
\end{tabular}

Herd Isolation (six different herds named A-F), IMI prevalence, sequence type characterization by MLST, RS-PCR analysis (genotype S, GTS; genotype B, GTB), mecA detection and virulence genes analysis ( $*$ ukE, leucotoxin $\mathrm{E}$ gene; cna, collagen adhesin-encoding gene; fmtb, gene encoding for cell wall-associated protein; scn, staphylococcal complement inhibitor gene; chp, chemotaxis inhibitory protein gene; lukM, leukotoxin M gene; clfA, clumping factor A gene; sea, enterotoxin $A$; sed, enterotoxin D; sej, enterotoxin J; seg, enterotoxin G, sei, enterotoxin I) 


\section{Growth conditions}

The strains were isolated and grown on Blood Agar plates and a single colony of the third passage in culture was transferred into $5 \mathrm{ml}$ of Brain Heart Infusion medium (BHI). Bacteria were grown overnight at $37{ }^{\circ} \mathrm{C}$. Cultures were subsequently diluted $1 / 100$ into $40 \mathrm{ml}$ of $\mathrm{BHI}$ and grown at $37{ }^{\circ} \mathrm{C}$. Optical density at $600 \mathrm{~nm}$ $\left(\mathrm{OD}_{600}\right)$ was performed hourly until mid-exponential phase $\left(\mathrm{OD}_{600}=0.4\right)$ was achieved. At the appropriate $\mathrm{OD}_{600}$, bacteria were pelleted by centrifugation at 10 $000 \mathrm{~g}$ for $2 \mathrm{~min}$; after surnatant removing, the pellet was resuspended in $500 \mu \mathrm{l}$ of saline solution $(\mathrm{NaCl} 0.9 \%)$ and centrifuged at $10000 \mathrm{~g}$ for $2 \mathrm{~min}$. The pellet was immediately used for RNA extraction and stored at $-20{ }^{\circ} \mathrm{C}$ for DNA extraction.

\section{Bacterial DNA and RNA extraction}

Genomic bacterial DNA was extracted using the protocol previously described [32], starting from step 2 . Total RNA was isolated using the NucleoSpin ${ }^{\circ}$ mRNA kit (Macherey-Nagel, Germany), according to the manufacturer protocol, in combination with TRIzol ${ }^{\circ}$ lysis. DNAs and RNAs were quantified using a NanoDrop ND-1000 spectrophotometer (NanoDrop Technologies, Wilmington, DE, USA) and RNAs quality was checked using the Agilent Bioanalyser 2100 (Agilent, Santa Clara, CA). Only RNA samples with RNA Integrity Number (RIN) values higher than 6.5 were used for the analysis. The isolated DNAs and RNAs were stored at -20 and $-80{ }^{\circ} \mathrm{C}$ until use, respectively.

\section{Library preparation and Miseq sequencing DNA}

Libraries were constructed using TruSeq PCR free Kit (Illumina, San Diego, CA, USA) following the manufacturer's instructions, sequenced in one $2 \times 300$-cycles Miseq run (Illumina, San Diego, CA, USA).

\section{RNA}

RNA was processed as previously described [27] with some variations. Briefly, bacterial rRNA was depleted with RiboZero rRNA removal kit for gram-positive organisms (Epicentre Illumina, Madison, WI, USA). RNA quality was assessed for each passage by the Agilent Bioanalyser 2100 (Agilent, Santa Clara, CA). Libraries were prepared using TruSeq ${ }^{\circ}$ RNA Sample Preparation v2 Kit (Illumina). Samples were sequenced on a Miseq Instrument (Illumina) in a $1 \times 50$-cycles run.

\section{Bioinformatics analysis}

Staph. aureus NCTC 8325 core gene evaluation and De-Novo Assembly of GTB/ST8 and GTS/ST398 strains. The quality of the raw sequencing reads was assessed by using FastQC software (http:// www.bioinformatics.babraham.ac.uk/projects/fastqc/). Adapter removal and quality trimming has been performed using Trimmomatic [33], with default parameters and nucleotide PHRED quality $>30$.

High-quality reads were mapped against the reference genome of NCTC 8325. BWA has been used as mapping software to detect common genes between GTS/ST398, GTB/ST8 and NCTC 8325. GTS/ST398 and GTB/ST8 reads were cross-mapped against NCTC 8325 genome. We applied quality filters by excluding those reads with more than four mismatches or those with mapping quality score (MAPQ) less than 15 in the resulting BAM files. To select genes present in the three genomes, we applied filters on coverage and depth. Briefly, only those genes that present $100 \%$ length coverage and a minimum 10X mean depth in the two mapping strains have been selected (Additional file 1). 2478 genes were selected and used in RNASeq analysis for quantification and differential expression. To perform the assembly the short-read assembly tool SPAdes 3.1.1 [34] was used. To obtain a reference assembly (ra) for each group of strains (genotype GTS/ST398 and GTB/ST8), the single assemblies (three for each group), were merged with CISA [35]. GTB/ST8 reference assembly (GTB/ST8ra) and GTS/ST398 reference assembly (GTS/ST398ra) were annotated with RAST [36]. To overcome false protein duplication and misassembly issues, we performed a reciprocal BLASTp within GTB/ST8ra set and GTS/ST398ra set separately. Whether a protein presented a perfect match (100\% sequence identity and 100\% length identity) with another one, only one of them was selected.

The protein sequences comparison between the strains (GTS/ST398, GTB/ST8) and the definition of the "core" (set of genes shared between GTB/ST8ra and GTS/ ST398ra) and "accessory" (set of unique genes for both genotypes) genomes was performed by using In Paranoid 4.1 software [37], a BLAST-based algorithm to compute protein homology analysis between two or more species. For GTB/ST8 and GTS/ST398 analysis, a cut-off of 0.9 for sequences overlap and the default values for the other options were used. The functional enrichment analysis was performed using the Fisher's test on the functional categories after Bonferroni multiple testing correction using R software version 3.0.3.

\section{Genomic comparison with other Staph. aureus reference strains}

For comparative analysis, reference genome sequences of 22 strains available in NCBI were used (Additional file 2). The genome similarities based on phylogenetic distances were analyzed using the Gegenees software [38]. A fragmented alignment in TBLASTX mode was performed with settings 500/500 and dendrogram was produced in SplitsTree 4 [39]. Visualization of genome 
comparisons was performed using BLAST Ring Image Generator [40].

\section{Transcriptomic analysis}

Transcriptome reads were mapped against the reference sequence of Staph. aureus NCTC 8325 genome with BWA aligner [41]. To generate a high-quality mapping for each sample, we applied quality filters by excluding those reads with more than four mismatches or those with mapping quality score (MAPQ) less than 15 . Read counts for gene relative abundance, differential expression analysis and statistical analysis were calculated as previously described $[42,43]$.

Differential expression analysis was performed on the gene set belonging to core genome of Staph. aureus NCTC8325 and the calculation of differential expression genes was performed with DESeq [44]. Differential expressed genes were selected with specific filters: 1) $p$-value less than 0.01 after Bonferroni correction (padj) 2) $\log 2 \mathrm{FC}>1.5$ or $<-1.5$. Functional categories annotation for each gene was extracted from COG database [45] and the Fisher's test was used for enrichment analysis after Bonferroni correction. All the statistical analyses were performed using $\mathrm{R}$ version 3.0.3. DNA-Seq and transcriptomic data were visualized using the Integrated Genomics Viewer IGV [46]. Transcriptomic data are available in Sequence Reads Archive (SRA) accession number SRX965931.

\section{Real Time PCR qRT-PCR}

Primers used for real-time PCR were designed using Primer Express software V2.0 (Applied Biosystems, Foster City, CA) and are listed in (Additional file 3). Pyrroline5 -carboxylate reductase (proC) was used as a reference gene [47]. Each sample was treated with DNAse and cDNAs were synthesized using GoScript ${ }^{\mathrm{mm}}$ Reverse Transcription System (Promega, Madison, WI) with random primers following manufacturer instruction. Real-time PCR was performed with 7900HT Fast Real-Time PCR System (Applied Biosystems, Carlsbad, California, USA) using Power SYBR ${ }^{\circ}$ Green PCR Master Mix (Applied Biosystems) according to manufacturer protocols. Data were analyzed with Sequence Detection Systems SDS Software (version 2.3).

\section{Pathway analysis}

Protein sequences from unique GTB/ST8 and GTS/ ST398 and differential expressed genes (DEGs) were used as queries in KOALA (KEGG Orthology And Links Annotation) tool for pathways reconstruction [48].

\section{fnbB partial re-sequencing}

Primers fnbB-F1 (5' -TTCTGCATGACCTTCTGCAC-3') and fnbB-R1 (5'-AGCAAGCGAAACACAAACAA-3') were used to amplify a portion from 1222 up to $2656 \mathrm{bp}$ of $f n b B$ genes (NCBI accession number: CP000253, region: $2577879 . . . . .2580632)$ in all the six strains. PCR was performed in a final volume of $25 \mu \mathrm{l}$, containing $60 \mathrm{ng}$ of DNA, $0.8 \mu \mathrm{M}$ of each primer, $12.5 \mu \mathrm{l}$ of GoTaq ${ }^{\circ}$ Long PCR Master Mix (Promega, Italy), with the following cycling parameters: $95{ }^{\circ} \mathrm{C}$ for $2 \mathrm{~min}, 30$ cycles of $94{ }^{\circ} \mathrm{C}$ for $30 \mathrm{~s}$, $56{ }^{\circ} \mathrm{C}$ for $30 \mathrm{~s}$ and $72{ }^{\circ} \mathrm{C}$ for $2 \mathrm{~min}$; and then $72{ }^{\circ} \mathrm{C}$ for $10 \mathrm{~min}$. PCR products were loaded in 1.5\% agarose gel. PCR products were purified with Wizard Clean-up (Promega, Italy), following manufacturer's instructions. Purified PCR products were sequenced bi-directionally (GATC Biotech, Konstanz, Germany) with primer fnbB-F1 and fnbB-R1. fnbB partial sequences determined in this study have been submitted to GenBank with accession numbers KY024702 and KY024703 for GTB/ST8 and GTS/ST398, respectively.

\section{Results}

In this study six strains of Staph. aureus previously described [4] as strictly associated with high and low withinherd IMI prevalence, respectively, were analysed in order to discover, thanks to comparative genomics and transcriptomics, potential pathogenic factors associated with the different clinical outcome found in the herds.

\section{Sequencing of GTB/ST8 and GTS/ST398 genotypes Genome assembly and Comparative Genomics}

Genomic diversity between the Staph. aureus GTB/ST8 and GTS/ST398 genotypes was assessed analyzing three DNA samples for each genotype that were deeply sequenced with an average production of 2,908,485 ( $\max$ $4,630,318$ and $\min 1,399,737)$ reads per sample. The sequencing reads from every sample were assembled obtaining an average of 95 number of large contigs (>500 nt) from all the samples (mean GTB/ST8: 50; mean GTS/ ST398: 139) (Additional file 4).

Three GTB/ST8 and three GTS/ST398 assemblies showed a high level of within group similarity, ranging from 91 to $99 \%$ and 95 to $98 \%$ respectively, whereas only a partial similarity (from 78 to $86 \%$ ) was observed between the two groups (Fig. 1a).

To create a single reference genome representing each group, all the single genotype-specific assemblies were merged together producing two reference assemblies, one for GTB/ST8 and one for GTS/ST398 with 19 (3.366.835 nt) and 291 (3.284.103 nt) large contigs, respectively. These reference assembly genomes, named GTB/ST8ra and GTS/ST398ra, respectively, were used for the genomic analysis in comparison with the genomes of other 22 Staph. aureus reference strains, fully sequenced and available in GenBank (Fig. 1b). The two genotypes GTS/ST398ra and GTB/ST8ra here analysed clustered better with the Staph. aureus ST398 prototype 


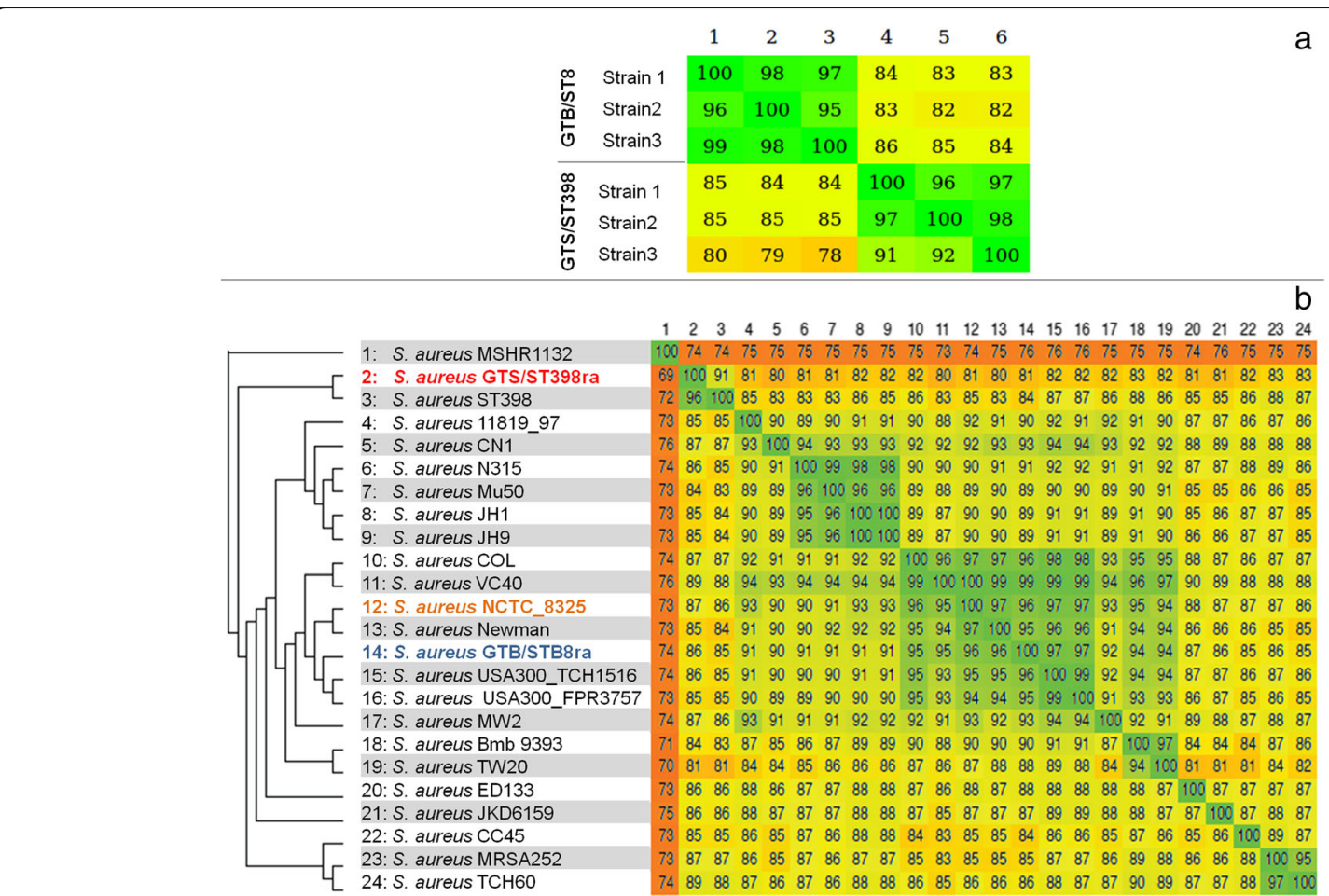

Fig. 1 a Percentage of similarity between the three GTB/ST8 and the three GTS/ST398strains. b Phylogenesis distances and percentage of similarity between the two reference assemblies GTB/ST8ra (blue) GTS/ST398ra (red) and other Staph. aureus strains. In brown the NCTC_8325 strain used as reference for RNASeq data analysis

and Staph. aureus TCH1516, respectively, the latter being a human ST8 reference strain.

\section{GTB/ST8ra and GTS/ST398ra genome comparison}

Two thousand six hundred sixty-seven and 2712 Coding DNA Sequences (CDS) were annotated from the prediction tool for GTB/ST8ra and GTS/ST398ra, respectively. Predicted proteins were functionally categorized using the COGs database. As expected, about 50\% were annotated with a functional role $(48.74 \% \mathrm{GTB} / \mathrm{ST}$ ra and $48.48 \%$ GTS/ST398ra, respectively). Protein homology analysis revealed that the majority of CDSs $(n=2247)$ was shared between the two groups of strains, since up to $84.25 \%$ and $82.85 \%$ of the CDSs belonged to the core genome of GTB/ST8ra and GTS/ST398ra, respectively (Additional file 5). The COGs distributions were similar in the two genomes: both GT8/ST8ra and GTS/ST398ra presented a set of unique genes belonging to "Phages, Prophages, Transposable elements, Plasmids" and "Virulence, Disease and Defence" categories that were significantly enriched ( $p$-value $<0.01)$ compared to the core genome. In addition, GTB/ST8ra was significantly enriched also in "Membrane Transport" genes (Fig. 2, Additional file 6). For both groups of strains, unique genes associated to virulence were prevalently attributed to "Adhesion function" and "Resistance to antibiotics and toxic compounds and toxin production" (Table 2).

\section{GTB/ST8 and GTS/ST398 transcriptomic comparison Transcriptomic analysis and $q R T-P C R$ validation}

RNA-Seq data covering the Staph. aureus genome were used to quantitatively compare gene expression levels between the two groups of strains grown in the exponential phase. Transcriptome reads were aligned against Staph. aureus NCTC8325 reference genome with an high read-mapping rate and high coverage for both genotypes (average: $93.25 \% \pm 1.39 \%$ ) (Additional file 7). Among the 2479 genes that were in common between the three genomes (GTS/ST398ra, GTB/ST8ra and NCTC8325), 237 differential expressed genes (DEGs) were found between the two groups with a distribution of $56.1 \%$ of the DEGs up-regulated in GTB/ST8 strains and $43.9 \%$ in GTS/ST398 strains (Additional file 8).

Four of these differentially expressed genes were validated by RT-PCR: SAOUHSC_00773, the LysM domain-containing protein; SAOUHSC_01181 an hypothetical proteins; SAOUHSC_01314, DNA-binding response regulator; SAOUHSC_01450the basic amino acid/polyamine antiporter, APA family protein. For each test, qPCR results confirmed RNA-Seq data: SAOUHSC_01314 not 


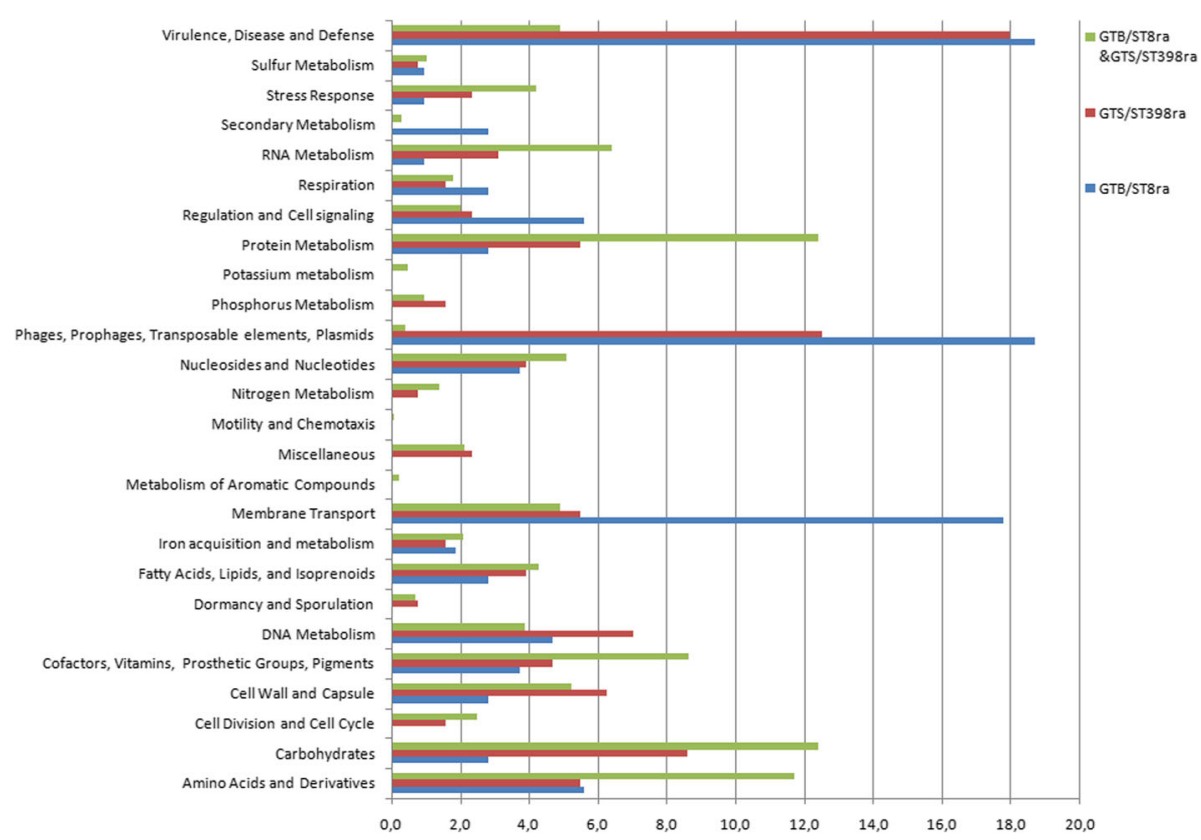

Fig. 2 Gene ontology (GO) categories comparison between annotated genes belonging to the core genome (shared GTB/ST8ra\&GTS/ST398ra genes, in green) and unique gene for GTB/ST8ra (blue) and GTS/ST398ra (brown). X axis indicates the percentage value of genes belonging to each categories reported

expressed in one of the two genotypes resulted in undetermined CT value, whereas the three differentially expressed genes SAOUHSC_00773, SAOUHSC_01181, SAOUHSC_01450 showed fold changes of 0.0538, 9.0972 and 0.1297 in qPCR respectively, comparable with the fold changes of $0.0694,91.4000$ and 0.0265 obtained from RNA-Seq (Additional file 9a, b).

\section{Functional analysis of transcriptomic data}

The comparison between the number of DEGs and the total number of genes present in the NCTC8325 reference genome, revealed that genes belonging to "Amino acid transport and metabolism" category varied significantly between the two genotypes (corrected $p$-value 3.86E-05). Other two categories, "Defence mechanism" and "Inorganic ion transport and metabolism" indicated a trend toward enrichment in DEGs list (Fig. 3).

Within the 42 annotated genes related to "Aminoacid transport and metabolism" pathway, only 9 were upregulated in GTB/ST8 (Table 3). Concerning "Defence mechanism" we found 34 annotated genes, within 14 and 20 up-regulated in GTB/ST8 and GTS/ST398, respectively. Finally, among the 24 DEGs belonging to "Inorganic ion transport and metabolism", 4 and 20 were up-regulated in GTB/ST8 and GTS/ST398, respectively (Table 3 ).

\section{Virulence and defence pathways analysis: comparison} between genomic and transcriptomic data

Functional and pathway enrichment analysis for integrated regulatory network of the two groups of strains was performed considering annotated genes from DNA-Seq and RNA-Seq experiments, grouped in the three dataset, i.e. gene exclusively present in GTB/ ST8ra, gene exclusively present in GTS/ST398ra and DEGs (Additional files 5 and 8).

Considering the functional categories belonging to bacterial invasion of epithelial cells and infection pathways, we found genes that were detected by using or (i) strain genotyping comparison or (ii) transcriptomic analysis or (iii) by the two combined approaches, as reported in Fig. 4. For example, from this analysis Fibronectin-Binding Protein B gene $(f n b B)$, an important adhesin involved not only in adhesion to cells but also in internalization by cells, was detected in both groups by means of a partial alignment between GTB/ST8ra and GTS/ST398ra protein sequence. In parallel, transcriptomic analysis revealed a variation in $f n b B$ expression, overexpressed in GTB/ST8 and down regulated in GTS/ST398 (Additional file $10 \mathrm{a}, \mathrm{b}, \mathrm{c}$ ). The nucleotide sequence between the two groups of strains was verified by sequencing a 1285 bp portion of $f n b B$ gene (Additional file 11). The nucleotide sequence was conserved within each group of strains and was high polymorphic between the two genotypes. Overall, GTS/ST398 showed a high polymorphism 
Table 2 Genes associated to virulence resulting different between the two reference genotypes (GTB/ST8ra and GTS/ST398ra)

\begin{tabular}{|c|c|c|c|c|}
\hline Sequence annotation (Features) & Subcategory & Function & GTB/ST8ra & GTS/ST398ra \\
\hline \multicolumn{5}{|l|}{ fig|6666666.84847.peg. } \\
\hline 1289 & 1 & Extracellular adherence protein of broad specificity Eap/Map & + & - \\
\hline 1290 & 1 & Extracellular adherence protein of broad specificity Eap/Map & + & - \\
\hline 150 & 2 & Fosfomycin resistance protein FosB & + & - \\
\hline 1807 & 1 & Virulence-associated cell-wall-anchored protein SasG (LPXTG motif) & + & - \\
\hline 1812 & 1 & Fibronectin binding protein FnbB & + & - \\
\hline 2863 & 1 & Adhesin of unknown specificity SdrC & + & - \\
\hline 2986 & 2 & Arsenate reductase (EC 1.20.4.1) & + & - \\
\hline 3003 & 1 & Predicted cell-wall-anchored protein SasC (LPXTG motif) & + & - \\
\hline 311 & 1 & Virulence-associated cell-wall-anchored protein SasG (LPXTG motif) & + & - \\
\hline 312 & 1 & Virulence-associated cell-wall-anchored protein SasG (LPXTG motif) & + & - \\
\hline 3121 & 3 & Leukotoxin LukD & + & - \\
\hline 3122 & 3 & Leukotoxin LukE & + & - \\
\hline 316 & 1 & Fibronectin binding protein FnbB & + & - \\
\hline 564 & 1 & Virulence-associated cell-wall-anchored protein SasG (LPXTG motif) & + & - \\
\hline 582 & 2 & Arsenate reductase (EC 1.20.4.1) & + & - \\
\hline 583 & 2 & Arsenic efflux pump protein & + & - \\
\hline 584 & 2 & Arsenical pump-driving ATPase (EC 3.6.3.16) & + & - \\
\hline 586 & 2 & Arsenical resistance operon repressor & + & - \\
\hline 618 & 1 & Protein A, von Willebrand factor binding protein Spa & + & - \\
\hline 930 & 1 & Cadmium resistance protein & + & - \\
\hline \multicolumn{5}{|l|}{ fig|6666666.84857.peg. } \\
\hline 100 & 2 & Predicted cell-wall-anchored protein SasA (LPXTG motif) & - & + \\
\hline 1028 & 1 & Tetracycline resistance protein TetM & - & + \\
\hline 1345 & 2 & Adhesin of unknown specificity SdrE & - & + \\
\hline 1462 & 1 & Two-component sensor histidine kinase BceS & - & + \\
\hline 1498 & 4 & Protein A, von Willebrand factor binding protein Spa & - & + \\
\hline 1574 & 1 & TetR family regulatory protein of MDR cluster & - & + \\
\hline 1856 & 2 & Collagen binding protein $\mathrm{Cna}$ & - & + \\
\hline 2046 & 1 & Fibronectin binding protein FnbB & - & + \\
\hline 2047 & 1 & Fibronectin binding protein FnbB & - & + \\
\hline 2308 & 1 & Predicted cell-wall-anchored protein SasC (LPXTG motif) & - & + \\
\hline 2309 & 1 & Predicted cell-wall-anchored protein SasC (LPXTG motif) & - & + \\
\hline 267 & 1 & Virulence-associated cell-wall-anchored protein SasG (LPXTG motif) & - & + \\
\hline 2840 & 1 & Copper-translocating P-type ATPase (EC 3.6.3.4) & - & + \\
\hline 2903 & 2 & Collagen binding protein $\mathrm{Cna}$ & - & + \\
\hline 317 & 1 & Spectinomycin 9-O-adenylyltransferase & - & + \\
\hline 334 & 2 & Clumping factor ClfB, fibrinogen binding protein & - & + \\
\hline 344 & 1 & Adhesin of unknown specificity SdrE & - & + \\
\hline 352 & 1 & Predicted cell-wall-anchored protein SasA (LPXTG motif) & - & + \\
\hline 510 & 1 & Adhesin of unknown specificity SdrE & - & + \\
\hline 512 & 1 & Adhesin of unknown specificity SdrC & - & + \\
\hline
\end{tabular}


Table 2 Genes associated to virulence resulting different between the two reference genotypes (GTB/ST8ra and GTS/ST398ra) (Continued)

\begin{tabular}{llll}
\hline 561 & 1 & Spectinomycin 9-O-adenylyltransferase & - \\
609 & 2 & Extracellular adherence protein of broad specificity Eap/Map & - \\
63 & 1 & Collagen binding protein Cna & - \\
\hline
\end{tabular}

(+) presence, (-) absence. The sequence annotation (Features) subcategory were: 1) Adhesion, 2) Resistance to antibiotics and toxic compounds, 3) Toxins and superantigens and 4) Bacteriocins, ribosomally synthesized antibacterial peptides. For each entry the Function was reported

compared to reference NCTC8325 strain sequence (83\% of identity), whereas no differences were observed for GTB/ ST8 (100\% of identity). Further, the protein translation for GTS/ST398 resulted in a truncated protein form.

Moreover as shown in Fig. 4, clumping factor B gene $(C l f B)$ and iron-regulated surface determinant protein $\mathrm{A}$ gene (IsdA) showed differentially expression by transcriptomic profiling (over-expressed and down regulated in GTB/ST8 and vice versa for GTS/ST398, respectively) (Additional file 12 a, b). Furthermore, the serineaspartate repeat-containing protein $\mathrm{C} / \mathrm{D} / \mathrm{E}$ gene $(\mathrm{SdrC}$ / $D / E)$ and eap/map protein gene (EaP/MaP) differed in protein sequence exclusively by DNASeq comparison (Additional file 13 a, b). Finally leukocidin/hemolysin gene $(H l g / L u c)$ was seen to be exclusively present and expressed in the GTB/ST8 strains, whereas the staphylococcal complement inhibitor SCIN (scn) was differentially expressed between the two groups, over-expressed in GTB/ST8 and down-regulated in GTS/ST398.

\section{Discussion}

Staph. aureus IMI clinical outcomes are highly variable and depend on several factors, including animal genetics, environmental conditions and strain-dependent factors. All these conditions should be correctly evaluated in order to predict the spread of bacterial strains within the herd. Here we achieved an in-depth characterization through NGS of six Staph. aureus strains previously genotyped as GTB/ST8 and GTS/ST398, differing in virulence properties such as within-herd Staph. aureus IMI prevalence [4].

These six strains belonged to two distinct clonal complexes and sequence types (CC8/ST8 for GTB/ST8, and CC398/ST398 for GTS/ST398), with a high intra-group similarity among the three strains associated to the same clonal complex (about 97\% and 95\% for GTB/ST8 and GTS/ST398, respectively), significantly supporting the creation of the reference assemblies as representative of these two lineages. Both genotypes clusterized in groups

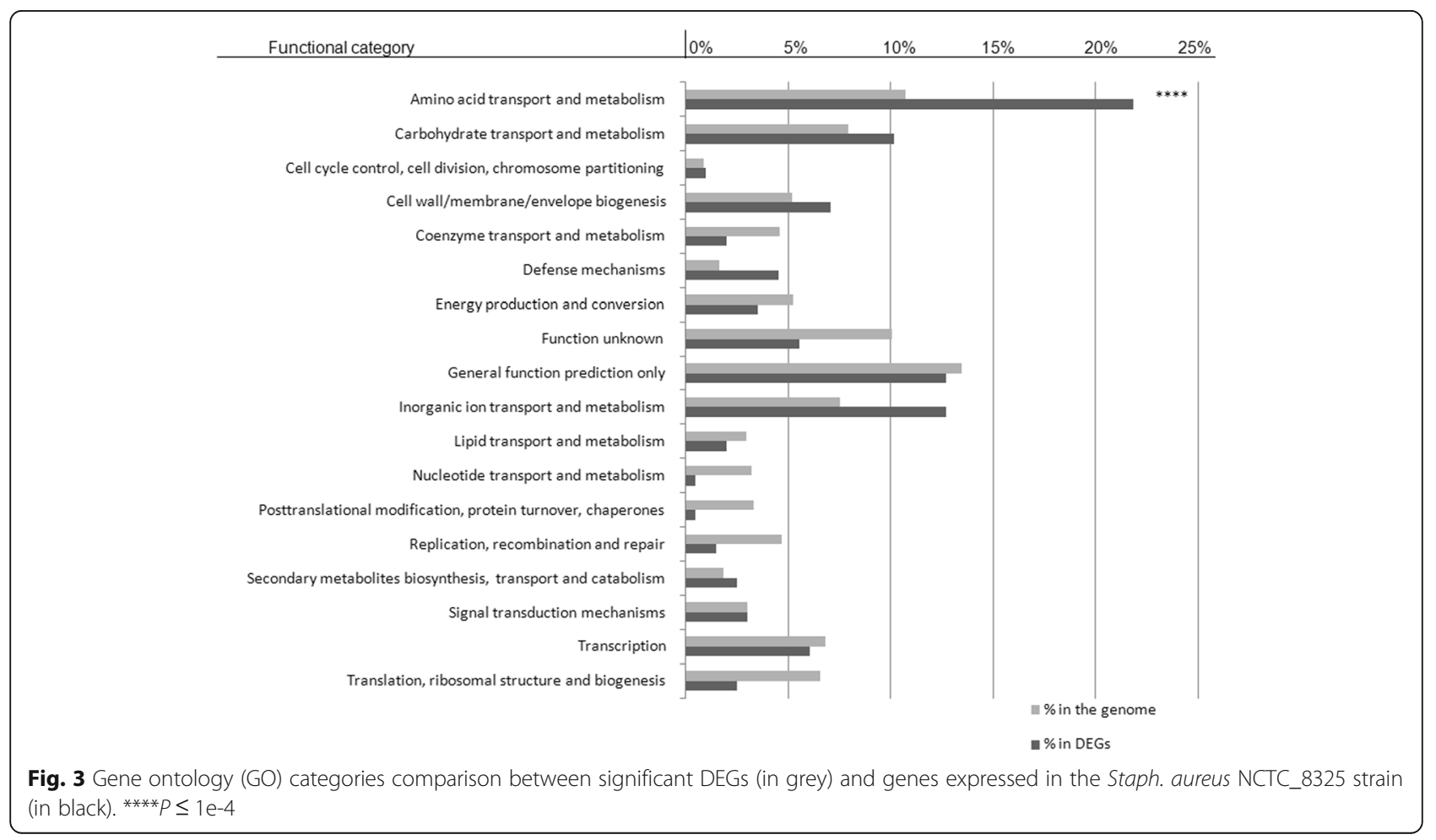


Table 3 DEGs between GTB/ST8 and GTS/ST398 strains

\begin{tabular}{|c|c|c|c|c|c|c|}
\hline LocusTag SAOUHSC & Function & Protein Description & padj & $\log 2 \mathrm{FC}$ & GTB/ST8 & GTS/ST398 \\
\hline 01451 & 1 & catalyzes the formation of 2-oxobutanoate from L-threonine; catabolic & $1.28 \mathrm{E}-56$ & -5.35 & $\downarrow$ & $\uparrow$ \\
\hline 01450 & 1 & Amino acid transporters & $3.35 \mathrm{E}-52$ & -5.25 & $\downarrow$ & $\uparrow$ \\
\hline _01452 & 1 & alanine dehydrogenase & 1.34E-50 & -5.16 & $\downarrow$ & $\uparrow$ \\
\hline _01448 & 1 & Permeases of the major facilitator superfamily & $1.82 \mathrm{E}-41$ & -5.16 & $\downarrow$ & $\uparrow$ \\
\hline _02969 & 1 & catalyzes the degradation of arginine to citruline and ammonia & $3.51 \mathrm{E}-22$ & -4.34 & $\downarrow$ & $\uparrow$ \\
\hline -02968 & 1 & $\begin{array}{l}\text { catalyzes the formation of ornithine and carbamylphosphate from } \\
\text { citrulline in the arginine catabolic pathway }\end{array}$ & $2.42 \mathrm{E}-15$ & -3.62 & $\downarrow$ & $\uparrow$ \\
\hline _00108 & 1 & Zinc peptidase & $8.34 \mathrm{E}-11$ & -6.03 & $\downarrow$ & $\uparrow$ \\
\hline _02967 & 1 & arginine/ornithine antiporter, putative & $2.00 \mathrm{E}-09$ & -2.65 & $\downarrow$ & $\uparrow$ \\
\hline _01803 & 1 & Gamma-aminobutyrate permease and related permeases & $2.86 \mathrm{E}-08$ & 2.41 & $\uparrow$ & $\downarrow$ \\
\hline _02767 & 1 & peptide $A B C$ transporter, peptide-binding protein, putative & $3.75 \mathrm{E}-08$ & -2.17 & $\downarrow$ & $\uparrow$ \\
\hline _02435 & 1 & Permeases of the major facilitator superfamily & 2.63E-07 & -2.42 & $\downarrow$ & $\uparrow$ \\
\hline _01307 & 1 & Threonine aldolase & $1.95 \mathrm{E}-06$ & -3.19 & $\downarrow$ & $\uparrow$ \\
\hline _02766 & 1 & peptide $A B C$ transporter, permease protein, putative & $3.06 \mathrm{E}-05$ & -1.95 & $\downarrow$ & $\uparrow$ \\
\hline _02763 & 1 & peptide $A B C$ transporter, ATP-binding protein, putative & 5.33E-05 & -1.97 & $\downarrow$ & $\uparrow$ \\
\hline _01825 & 1 & Cysteine sulfinate desulfinase/cysteine desulfurase and related enzymes & $5.72 \mathrm{E}-05$ & 1.95 & $\uparrow$ & $\downarrow$ \\
\hline _01320 & 1 & catalyzes the formation of L-aspartate 4-semialdehyde from L-homoserine & 5.97E-05 & -1.71 & $\downarrow$ & $\uparrow$ \\
\hline _00076 & 1 & ornithine cyclodeaminase, putative & $6.44 \mathrm{E}-05$ & -2.70 & $\downarrow$ & $\uparrow$ \\
\hline _01833 & 1 & $\begin{array}{l}\text { catalyzes the formation of 3-phosphonooxypyruvate from 3-phospho- } \\
\text { D-glycerate in serine biosynthesis; }\end{array}$ & 7.00E-05 & -1.77 & $\downarrow$ & $\uparrow$ \\
\hline 02740 & 1 & drug transporter, putative & 0.000142 & 1.65 & $\uparrow$ & $\downarrow$ \\
\hline _02697 & 1 & amino acid ABC transporter, ATP-binding protein, putative & 0.000231 & 1.57 & $\uparrow$ & $\downarrow$ \\
\hline _02825 & 1 & Lactoylglutathione lyase and related lyases & 0.000256 & -2.77 & $\downarrow$ & $\uparrow$ \\
\hline -00733 & 1 & catalyzes the formation of L-histidinol phosphate in histidine biosynthesis & 0.000257 & -1.78 & $\downarrow$ & $\uparrow$ \\
\hline _01321 & 1 & catalyzes the formation of L-threonine from O-phospho-L-homoserine & 0.000283 & -1.60 & $\downarrow$ & $\uparrow$ \\
\hline -00075 & 1 & siderophore biosynthesis protein SbnA & 0.00032 & -2.62 & $\downarrow$ & $\uparrow$ \\
\hline _02559 & 1 & ureases & 0.00039 & -2.37 & $\downarrow$ & $\uparrow$ \\
\hline _01991 & 1 & $A B C$ transporter, permease protein, putative & 0.00047 & 1.83 & $\uparrow$ & $\downarrow$ \\
\hline _01991 & 1 & $A B C$ transporter, permease protein, putative & 0.00047 & 1.83 & $\uparrow$ & $\downarrow$ \\
\hline _02765 & 1 & nickel $A B C$ transporter, permease protein, putative & 0.000471 & -1.75 & $\downarrow$ & $\uparrow$ \\
\hline _02433 & 1 & Predicted amino acid racemase & 0.000512 & -1.60 & $\downarrow$ & $\uparrow$ \\
\hline _02764 & 1 & peptide $A B C$ transporter, ATP-binding protein, putative & 0.000687 & -1.70 & $\downarrow$ & $\uparrow$ \\
\hline 02561 & 1 & ureases & 0.000724 & -1.65 & $\downarrow$ & $\uparrow$ \\
\hline _00421 & 1 & Cysteine synthase & 0.000785 & -1.60 & $\downarrow$ & $\uparrow$ \\
\hline 01319 & 1 & $\begin{array}{l}\text { catalyzes the formation of } 4 \text {-phospho- } L \text {-aspartate from } L \text {-aspartate } \\
\text { and ATP; lysine and threonine sensitive }\end{array}$ & 0.000879 & -2.01 & $\downarrow$ & $\uparrow$ \\
\hline _00740 & 1 & Permeases of the drug/metabolite transporter (DMT) superfamily & 0.001181 & 1.71 & $\uparrow$ & $\downarrow$ \\
\hline _02839 & 1 & L-serine dehydratase, iron-sulfur-dependent, alpha subunit & 0.001587 & -1.51 & $\downarrow$ & $\uparrow$ \\
\hline _01395 & 1 & aspartate-semialdehyde dehydrogenase & 0.001826 & -1.64 & $\downarrow$ & $\uparrow$ \\
\hline _00703 & 1 & quinolone resistance norA protein, putative & 0.002597 & 1.67 & $\uparrow$ & $\downarrow$ \\
\hline _02558 & 1 & UreA, with UreB and UreC & 0.005062 & -2.29 & $\downarrow$ & $\uparrow$ \\
\hline _01990 & 1 & amino acid ABC transporter, ATP-binding protein, putative & 0.005951 & 1.50 & $\uparrow$ & $\downarrow$ \\
\hline -02932 & 1 & $\begin{array}{l}\text { catalyzes the oxidation of choline to betaine aldehyde and betain } \\
\text { aldehyde to glycine betaine }\end{array}$ & 0.006268 & -1.53 & $\downarrow$ & $\uparrow$ \\
\hline
\end{tabular}


Table 3 DEGs between GTB/ST8 and GTS/ST398 strains (Continued)

\begin{tabular}{|c|c|c|c|c|c|c|}
\hline 01394 & 1 & $\begin{array}{l}\text { catalyzes the formation of 4-phospho-L-aspartate from } L \text {-aspartate and } \\
\text { ATP, in Bacillus, lysine sensitive; regulated by response to starvation, }\end{array}$ & 0.006704 & -1.68 & $\downarrow$ & $\uparrow$ \\
\hline _00170 & 1 & peptide/nickel transport system substrate-binding protein & 0.008873 & -1.55 & $\downarrow$ & $\uparrow$ \\
\hline _02972 & 2 & immunodominant antigen $B$ IsaB & $6.70 \mathrm{E}-24$ & 5.79 & $\uparrow$ & $\downarrow$ \\
\hline _01079 & 2 & neurofilament protein & $7.69 E-23$ & -4.51 & $\downarrow$ & $\uparrow$ \\
\hline _02127 & 2 & staphopain thiol proteinase & $4.50 \mathrm{E}-18$ & -3.61 & $\downarrow$ & $\uparrow$ \\
\hline _01933 & 2 & type I restriction-modification system, M subunit & $5.20 \mathrm{E}-18$ & -5.10 & $\downarrow$ & $\uparrow$ \\
\hline _02708 & 2 & gamma-hemolysin h-gamma-ii subunit, putative & 4.61E-17 & -3.60 & $\downarrow$ & $\uparrow$ \\
\hline _01115 & 2 & staphylococcal complement inhibitor SCIN & $3.05 \mathrm{E}-15$ & 5.06 & $\uparrow$ & $\downarrow$ \\
\hline _01135 & 2 & anti protein (phenol soluble modulin) & $2.18 \mathrm{E}-13$ & -3.07 & $\downarrow$ & $\uparrow$ \\
\hline _01964 & 2 & signal transduction protein TRAP & $3.38 \mathrm{E}-13$ & 3.35 & $\uparrow$ & $\downarrow$ \\
\hline _00668 & 2 & $A B C$ transporter permease, putative & $3.60 \mathrm{E}-13$ & 3.99 & $\uparrow$ & $\downarrow$ \\
\hline _02420 & 2 & multidrug resistance protein SepA & $2.58 \mathrm{E}-11$ & 3.99 & $\uparrow$ & $\downarrow$ \\
\hline _02963 & 2 & clumping factor B, putative & $2.92 \mathrm{E}-11$ & 2.75 & $\uparrow$ & $\downarrow$ \\
\hline 02419 & 2 & methicillin resistance protein $\mathrm{FmtB}$ & $2.69 \mathrm{E}-10$ & 5.00 & $\uparrow$ & $\downarrow$ \\
\hline _00256 & 2 & staphyloxanthin biosynthesis protein, secretory antigen precursor SsaA & $1.48 \mathrm{E}-09$ & -2.69 & $\downarrow$ & $\uparrow$ \\
\hline _02802 & 2 & fibronectin binding protein $B$, putative & $3.09 \mathrm{E}-09$ & 2.32 & $\uparrow$ & $\downarrow$ \\
\hline _02709 & 2 & leukocidin s subunit precursor, putative & 1.30E-08 & -2.45 & $\downarrow$ & $\uparrow$ \\
\hline 02710 & 2 & leukocidin $\mathrm{f}$ subunit precursor & $1.50 \mathrm{E}-08$ & -2.43 & $\downarrow$ & $\uparrow$ \\
\hline -01084 & 2 & Heme ABC transporter & 7.71E-08 & -2.72 & $\downarrow$ & $\uparrow$ \\
\hline _01081 & 2 & heme transporter IsdA & $2.63 \mathrm{E}-07$ & -2.11 & $\downarrow$ & $\uparrow$ \\
\hline _01136 & 2 & anti protein (phenol soluble modulin) & $3.38 \mathrm{E}-07$ & -2.57 & $\downarrow$ & $\uparrow$ \\
\hline 01121 & 2 & alpha-hemolysin precursor & $4.12 \mathrm{E}-07$ & -2.07 & $\downarrow$ & $\uparrow$ \\
\hline _02696 & 2 & fmhA protein, putative & $4.40 \mathrm{E}-07$ & -2.29 & $\downarrow$ & $\uparrow$ \\
\hline -01082 & 2 & heme transporter IsdC & $1.40 \mathrm{E}-06$ & -2.81 & $\downarrow$ & $\uparrow$ \\
\hline _00354 & 2 & putative enterotoxin & $1.43 \mathrm{E}-05$ & 3.22 & $\uparrow$ & $\downarrow$ \\
\hline _02740 & 2 & drug transporter, putative & 0.000142 & 1.65 & $\uparrow$ & $\downarrow$ \\
\hline _02129 & 2 & staphostatin A & 0.000392 & -2.16 & $\downarrow$ & $\uparrow$ \\
\hline _00395 & 2 & homology to known superantigen proteins & 0.000545 & 2.81 & $\uparrow$ & $\downarrow$ \\
\hline 02718 & 2 & ABC Transporters & 0.000631 & -2.09 & $\downarrow$ & $\uparrow$ \\
\hline 01932 & 2 & type I restriction-modification enzyme, S subunit, EcoA family, putative & 0.000692 & 2.06 & $\uparrow$ & $\downarrow$ \\
\hline _00998 & 2 & fmt protein, putative & 0.00072 & 1.59 & $\uparrow$ & $\downarrow$ \\
\hline _00261 & 2 & type VII secretion protein EssB & 0.000785 & -1.84 & $\downarrow$ & $\uparrow$ \\
\hline _00426 & 2 & $A B C$ transporter, substrate-binding protein, putative & 0.001147 & -1.74 & $\downarrow$ & $\uparrow$ \\
\hline _00397 & 2 & type I restriction-modification system, M subunit & 0.002795 & 1.56 & $\uparrow$ & $\downarrow$ \\
\hline 02719 & 2 & methicillin resistance protein $\mathrm{FmtB}$ & 0.00383 & -2.08 & $\downarrow$ & $\uparrow$ \\
\hline _00249 & 2 & ABC-2 type transport system ATP-binding protein & 0.005426 & -1.83 & $\downarrow$ & $\uparrow$ \\
\hline 01448 & 3 & Permeases of the major facilitator superfamily & $1.82 \mathrm{E}-41$ & -5.16 & $\downarrow$ & $\uparrow$ \\
\hline-02420 & 3 & Permeases of the major facilitator superfamily & $2.58 \mathrm{E}-11$ & 3.99 & $\uparrow$ & $\downarrow$ \\
\hline _01085 & 3 & multidrug resistance protein SepA & 1.17E-08 & -3.16 & $\downarrow$ & $\uparrow$ \\
\hline -02687 & 3 & ABC-type Fe3 + -hydroxamate transport system, periplasmic component & $8.11 \mathrm{E}-08$ & 2.50 & $\uparrow$ & $\downarrow$ \\
\hline _02435 & 3 & formate/nitrite transporter, putative & 2.63E-07 & -2.42 & $\downarrow$ & $\uparrow$ \\
\hline _01087 & 3 & Permeases of the major facilitator superfamily & $9.18 \mathrm{E}-07$ & -3.16 & $\downarrow$ & $\uparrow$ \\
\hline
\end{tabular}


Table 3 DEGs between GTB/ST8 and GTS/ST398 strains (Continued)

\begin{tabular}{|c|c|c|c|c|c|c|}
\hline -01086 & 3 & iron compound $A B C$ transporter, permease protein & $9.72 \mathrm{E}-07$ & -2.74 & $\downarrow$ & $\uparrow$ \\
\hline _00105 & 3 & iron compound $\mathrm{ABC}$ transporter, permease protein, putative & $1.76 \mathrm{E}-06$ & -2.81 & $\downarrow$ & $\uparrow$ \\
\hline _00074 & 3 & phosphonate $A B C$ transporter, substrate-binding protein, putative & 2.13E-06 & -1.95 & $\downarrow$ & $\uparrow$ \\
\hline _02864 & 3 & periplasmic binding protein, putative & 1.36E-05 & -2.13 & $\downarrow$ & $\uparrow$ \\
\hline _02766 & 3 & ferrous iron transport protein $B$ & 3.06E-05 & -1.95 & $\downarrow$ & $\uparrow$ \\
\hline _02763 & 3 & peptide $A B C$ transporter, permease protein, putative & 5.33E-05 & -1.97 & $\downarrow$ & $\uparrow$ \\
\hline _00423 & 3 & peptide $A B C$ transporter, ATP-binding protein, putative & 0.000135 & -2.30 & $\downarrow$ & $\uparrow$ \\
\hline _02740 & 3 & ABC-type metal ion transport system, ATPase component & 0.000142 & 1.65 & $\uparrow$ & $\downarrow$ \\
\hline 01893 & 3 & drug transporter, putative & 0.000208 & -2.53 & $\downarrow$ & $\uparrow$ \\
\hline _02765 & 3 & arsenical pump membrane protein subfamily & 0.000471 & -1.75 & $\downarrow$ & $\uparrow$ \\
\hline _00424 & 3 & nickel $A B C$ transporter, permease protein, putative & 0.000582 & -2.47 & $\downarrow$ & $\uparrow$ \\
\hline _02764 & 3 & $A B C$ transporter, permease protein, putative & 0.000687 & -1.70 & $\downarrow$ & $\uparrow$ \\
\hline _00325 & 3 & peptide ABC transporter, ATP-binding protein, putative & 0.000864 & -2.44 & $\downarrow$ & $\uparrow$ \\
\hline _00104 & 3 & Predicted periplasmic lipoprotein involved in iron transport & 0.001514 & -2.10 & $\downarrow$ & $\uparrow$ \\
\hline _00703 & 3 & amino acid ABC transporter, ATP-binding protein, putative & 0.002597 & 1.67 & $\uparrow$ & $\downarrow$ \\
\hline -02865 & 3 & quinolone resistance norA protein, putative & 0.004758 & -2.19 & $\downarrow$ & $\uparrow$ \\
\hline _00102 & 3 & ferrous iron transport protein $\mathrm{A}$ & 0.00479 & -1.91 & $\downarrow$ & $\uparrow$ \\
\hline _00103 & 3 & phosphonates $A B C$ transporter, permease protein CCO363, putative & 0.008185 & -1.78 & $\downarrow$ & $\uparrow$ \\
\hline
\end{tabular}

For each Locus Tag, Function: 1) Amino acid transport and metabolism, 2) Defence mechanisms, and 3) Inorganic ion transport and metabolism; Protein Description, $P$-value adjusted (padj), log2FoldChange (log2FC) and $(\uparrow)$ up and $(\downarrow)$ down-regulation were reported

that include strains of human origin: GTS/ST398 showed high similarity with the prototype of Staph. aureus ST398, SO385, isolated from human endocarditis [49], whereas GTB/ST8 to Staph. aureus TCH1516, a methicillin susceptible ST8 strain, isolated from an adolescent patient with severe sepsis syndrome [50]. Recent studies on these CCs $[4,13]$ showed a closed genetic relationship between $\mathrm{CC} 8$ isolated from dairy cow mastitis and human $\mathrm{CC} 8$, suggesting human-to-bovine jump. On the other hand, the presence of CC398 strains was described only in herds with IMI prevalence lower than $5 \%$ [4]. In the present study, a comparison of the genome sequences of these strains with a core genome (set of genes shared between GTB/ST8ra and GTS/ ST398ra) revealed about $17 \%$ of differences for their gene content, with a relevant enrichment in genes associated with virulence properties. Both groups of strains showed differences in several genes associated to virulence factors and some of them were present in only one of the two genotypes.

Furthermore, the transcriptomic profiling for both groups of strains confirmed the functional enrichment for genes related to adaptation and propensity to chronicity. Interestingly, GTB/ST8ra showed higher expression of signal transduction Target of RNAIIIactivating Protein TRAP, that leads to the activation of agr system, resulting in the expression of several virulence factors. As previously described [51, 52], the protein TRAP activates RNAIII synthesis by RNAIII- activating protein (RAP) system, increasing the pathogenic potential of the bacteria.

Contemporary, the integrated pathway analysis between the two genotypes of Staph. aureus genes involved in pathogenicity showed an interesting variation in the microbial surface component recognizing adhesive matrix molecule (MSCRAMM), whose function includes adhesion to and invasion in host cells and tissues, evasion of immune responses and biofilm formation [53]. As well known, the $f n b \mathrm{~B}$ gene is a multifunctional MSCRAMM, which recognizes fibronectin, fibrinogen and elastin and promoting the internalization of Staph. aureus into epithelial and endothelial cell mediating bacterial invasion $[54,55]$. Most Staph. aureus strains can express two distinct fibronectin-binding proteins (FnBPA and FnBPB), which both mediate adhesion to fibrinogen, elastin and fibronectin. The GTB/ST8 and GTS/ST398 strains, analysed in this study, presented the two fibronectin-binding proteins but only $f n b \mathrm{~B}$ showed changes in genomic and transcriptomic analyses between these two groups. The $f n b \mathrm{~B}$ gene showed high variability between the two genotypes, revealing a high level of polymorphisms that lead to a premature stop codon and a truncated form of the protein for GTS/ST398 strains. Similar results were previously published by McCarthy and colleagues [56], which postulated that the truncated FnBPB form could affect Staph. aureus colonisation and infection. Also Burke and co-workers found different FnBPB isotypes in diverse STs Staph. aureus strains, revealing an association between 


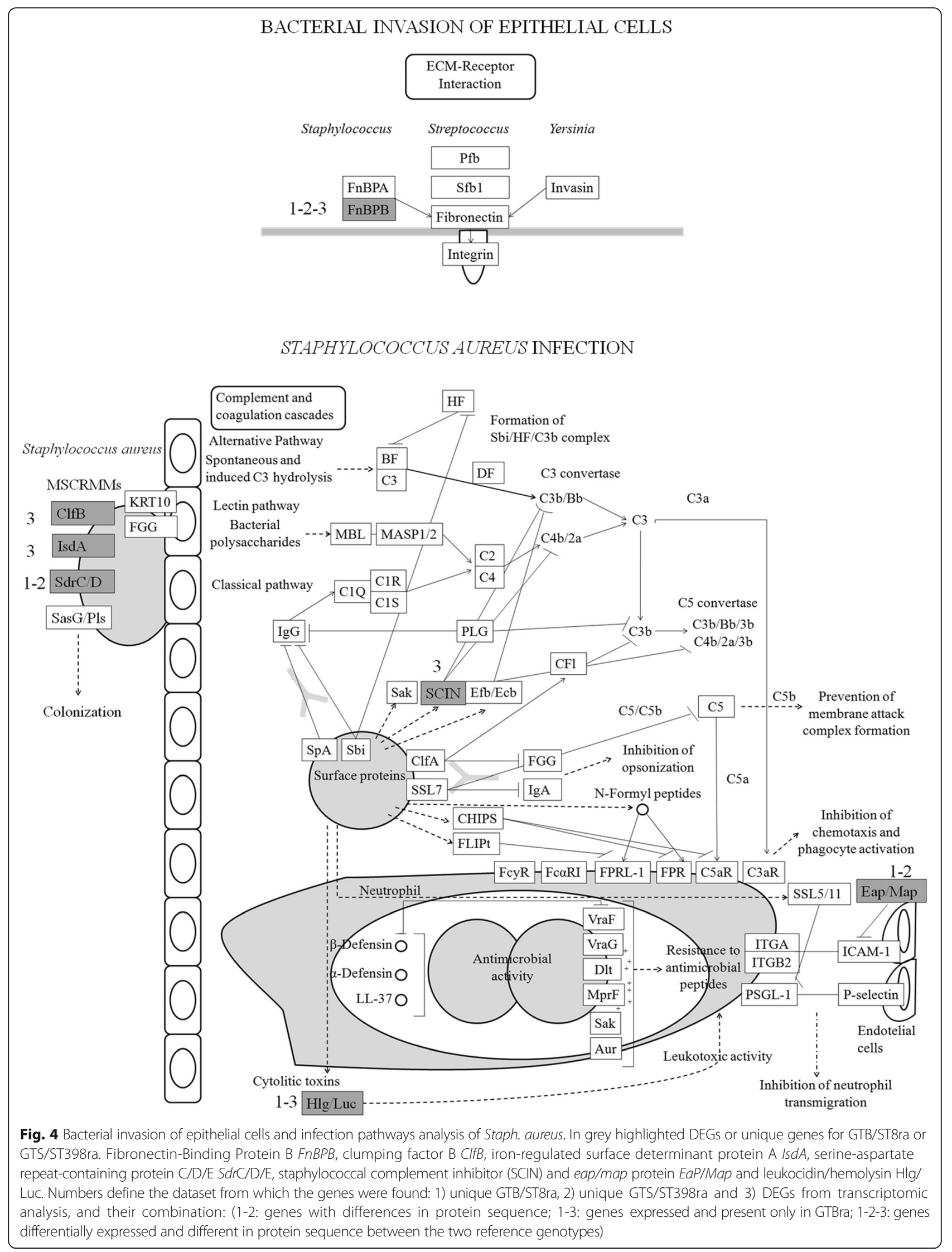


this gene and the invasiveness [57]. And more, the presence of protein variations for both groups of strains suggests a different affinity for fibronectin, necessary for the internalization of Staph. aureus into host cells [23].

In addition, $C l f B$ and $S d r C / D / E$ genes encoding for MSCRAMMs proteins, whose functions are related to adhesion and colonization [58, 59], showed differences by transcriptomic and genomic analyses in both genotypes, respectively, indicating that surface adhesins are not only present/absent, but also variable amongst lineages of Staph. aureus [56], such as GTB/ST8 and GTS/ ST398. Polymorphisms in these genes are well known and used to Multilocus Variable Number Tandem Repeat Fingerprinting (MLVF), a genotyping method for epidemiological studies [60]. Other multi-functional proteins, such as the "Staph. aureus surface G Sas G protein the iron-dependent adhesion IsdA, IsdB, IsdC", over-expressed in GTS/ST398, play a role in biofilm formation [61, 62]. The adhesive properties displayed by MSCRAMM proteins reside within the cell surface; however, several important adhesins are also formally secreted from the bacterial cell. The "Secreted Expanded Repertoire Adhesive Molecules (SERAM) extracellular adherence protein" (eap) is nearly ubiquitously distributed amongst Staph. aureus strains and appears to function as a virulence determinant in animal models of chronic infection [63]. Eap gene was proposed as novel target for specific identification of Staph. aureus [64]. According to our results the sequence alignment of eap gene from all Staph. aureus genomes published to date revealed a significant polymorphism in this gene [65]. As stated by McCarthy et al. [56], the genetic variation in Staph. aureus surface and immune evasion genes is lineage associated and carries a range of unique variants in order to improve the adaptation of this microorganism to different host species.

Finally, the staphylococcal complement inhibitor (scn), over-expressed in GTB/ST8 and down-regulated in GTS/ST398, produced by the Staph. aureus during the early phase of infection, helped the microorganism to survive into the host [66], preventing both chemotaxis and phagocytosis. The fact that surface and immune evasion proteins are different between lineages suggests that they are essential for virulence, opening a window for further investigations.

\section{Conclusions}

In conclusion, our analysis proves that integration of RNA-Seq and DNA-Seq data well depicts Staph. aureus strains associated with different within-herd IMI prevalence in dairy cows. Our results disclosed congruent patterns of genetic variation in colonization and invasion factors between GTB/ST8 and GTS/ST398 strains. Notwithstanding, results highlight a high number of unknown genes differing between genotypes, whose unknown functionality lacks a direct association with virulence function. Overall, the fine genomic characterization of these strains was a first step towards developing strategies able to provide new insights into mechanisms associated to Staph. aureus mastitis, including genomic comparison of a larger set of high and low diffusive strains, improvement of Staph. aureus reference strains annotation and new ad hoc bioinformatic tools.

\section{Additional files}

Additional file 1: GTS/ST398 and GTB/ST8 reads cross-mapped against NCTC 8325 genome and selected and used in RNASeq analysis for quantification and differential expression analysis. (XLSX $183 \mathrm{~kb}$ )

Additional file 2: List of the 22 Staph. aureus strains available in NCBI used in this study for genomic comparative analysis. (DOCX $22 \mathrm{~kb}$ )

Additional file 3: Primer list used for Real-Time-PCR experiments. (DOCX $17 \mathrm{~kb}$ )

Additional file 4: Sequencing results for three GTB/ST8 and three GTS/ ST398 strains. A) Assembly statistics for each strain: number of total contig obtained ( $\mathrm{N}^{\circ}$ of contigs), number of contig bigger that $500 \mathrm{nt}$ in size ( $\mathrm{N}^{\circ}$ of contigs $>500$ ), max length of the contig (Max contig length), median of contig lengths (N50), total genome assembled (Total assembled) were reported. B) Sequencing mapping GTS/ST398 vs GTB/ST8 and NCTC8325 statistics for each strain: number of total reads (Raw reads), number of reads mapped on NCTC8325 reference (Mapping reads), the percentage (Mapping rate (\%)), the average sequencing depth (Mean Depth (fold)) and the percentage of genome reference coverage (Coverage (\%)) were reported. C) Sequencing mapping GTB/ ST8 vs GTS/ST398 and NCTC8325 statistics for each strain: number of total reads (Raw reads), number of reads mapped on NCTC8325 reference (Mapping reads), the percentage (Mapping rate (\%)), the average sequencing depth (Mean Depth (fold)) and the percentage of genome reference coverage (Coverage (\%)) were reported. (DOCX 39 kb)

Additional file 5: List of shared and unique genes for single reference sequence representing genotype GTB/ST8ra and GTS/ST398ra. The gene annotation (Category, Subcategory, Subsystem, Role) was reported for each entry. (XLS 762 kb)

Additional file 6: Functional enrichment analysis of COGs distributions calculated by using the Fisher's test and Bonferroni multiple testing correction for GTB/ST8ra and GTS/ST398ra. (XLSX 17 kb)

Additional file 7: RNA sequencing results for the three GTB/ST8 and th three GTS/ST398 strains. Mapping vs NCTC8325 statistics for each strain: number of total reads (Raw reads), number of reads mapped on NCTC8325 reference (Maping reads) and percentage (\% Mapping), total CDS detected (CDS detected) and percentage of CDS vs reference CDS (\%CDS detected), distribution of CDS detected on mRNA (\% mRNA), rRNA (\% rRNA) and intergenic region (\% Intergenic). (DOCX $30 \mathrm{~kb}$ )

Additional file 8: Differential expressed genes (DEGs) between the three GTB/ST8 and the three GTS/ST398 strains. GTS/ST398 (1_2_3)_all CDS, GTB/ST8 (1_2_3)_all CDS, log2FoldChange, padj, protein and function class description were reported for each locus tag. In bold gene related to defense mechanism in italic gene validate by Real Time PCR experiment. (XLSX $33 \mathrm{~kb}$ )

Additional file 9: a) Real Time Fold Change variation and b) Fold change average between two reference genotypes GTB-ST8 and GTS-ST398 for three selected genes: SAOUHSC_00773, SAOUHSC_01181, SAOUHSC_01450. (DOC $34 \mathrm{~kb}$ )

Additional file 10: Fibronectin-Binding Protein B FnBpB comparison between Staph. aureus GTB/ST8ra and GTS/ST398ra. a) FnBpB protein sequence for GTB/ST8ra (>fig|6666666.84847.peg.316 and GTS/ST398ra (>fig|6666666.84857.peg.2046, >fig|6666666.84857.peg.2047) b) Protein blast between GTB/ST8ra and GTS/ST398ra. c) Integrative Genomics Viewer (IGV) view comparison between three Staph. GTB/ST8 and three 
GTS/ST398 strains mapped on Staph. aureus NCTC 8325 strain with reads from DNASeq or RNA-Seq experiments. (DOCX $176 \mathrm{~kb}$ )

Additional file 11: Sequence alignment for a $1285 \mathrm{bp}$ portion of $\mathrm{fnbB}$ gene (from position 1297up to 2582; NCBI accession number: CP000253, region: $2577879 . \ldots .2580632)$ in all the six strains. In figure, gene sequence for GTS/ST398 (1-2-3), GTB/ST8 (1-2-3), and the NCTC8325 strain in the homologous position are presented. (DOCX $670 \mathrm{~kb}$ )

Additional file 12: Integrative Genomics Viewer (IGV) view comparison of a) clumping factor B ClfB and b) protein A IsdA, between Staph. aureus three GTB/ST8 and three GTS/ST398 strains mapped on Staph. aureus NCTC 8325 strain with reads from DNASeq or RNASeq experiment. (DOCX $316 \mathrm{~kb}$ )

Additional file 13: Serine-aspartate repeat-containing protein C/D/E $\mathrm{SdrC/D/E}$ and eap, map protein EaP/MaP comparison between Staph. aureus GTB/ST8ra and GTS/ST398ra. a) SdrC/D/E protein sequenze for GTB/ST8ra (>fig|6666666.84847.peg.2863) and GTS/ST398ra (>fig|6666666.84857.peg.510); Eap/Map protein sequence for GTB/ ST8ra (>fig|6666666.84847.peg.1290) and GTS/ST398ra (>fig|6666666.84857.peg.609). b) Protein blast for SdrC/D/E and Eap/ Map between GTB/ST8ra and GTS/ST398ra. (DOCX $42 \mathrm{~kb}$ )

\section{Abbreviations}

BHI: Brain heart infusion; CDS: Coding DNA sequence; DNA-Seq: DNA sequencing; GTB: Genotype B; GTS: Genotype S; IMI: Intra-mammary infection; MLST: Multi locus sequence type; NGS: Next generation sequencing; RNA-Seq: RNA sequencing; RS-PCR: Repetitive-sequence PCR; RT-PCR: Real time PCR; ST: Sequence type; Staph. aureus: Staphylococcus aureus

\section{Acknowledgment}

None.

\section{Funding}

This research was supported by the Italian Ministry of Education, Universities and Research for the project "Progetto Bandiera INTEROMICS - Sottoprogetto 1: Sviluppo di Infrastrutture di Bioinformatiche per le applicazioni OMICS in Biomedicina" and the Lombardy Region: Project N. 1745 - MASTFIELD "Applicazione di sistemi molecolari innovativi per il controllo in campo delle mastiti bovine".

\section{Availability of data and materials}

Transcriptomic data have been deposited in Sequence Reads Archive (SRA) accession number SRX965931. fnbB partial sequences have been deposited to GenBank with accession numbers KY024702 and KY024703 for GTB/ST8 and GTS/ST398 respectively.

\section{Authors' contributions}

EC, PC, ML and BC conceived the study. ML collected and cultured the samples. $E C$ and $P C$ performed the DNA and RNA extraction, libraries preparation and sequencing. AP and SP carried out the genome assemblies, annotations, performed the (phylo)genomic analyses, and transcriptomic analysis. EC carried out pathway analysis, wrote the manuscript and generated the figures. ML, AS and BC read and approved the final manuscript. All authors read and approved the final manuscript.

\section{Competing interest}

The authors declare that they have no competing interests.

\section{Consent to publication}

Not applicable.

\section{Ethics approval and consent to participate}

Not applicable.

\section{Author details}

'Istituto di Biologia e Biotecnologia Agraria, CNR, via Einstein, 26900 Lodi, Italy. ${ }^{2}$ Istituto di Tecnologie Biomediche, CNR, Via Fratelli Cervi 93, 20090 Segrate, Milano, Italy. Istituto Zooprofilattico Sperimentale della Lombardia e dell'Emilia, Sezione di Lodi, via Einstein, 26900 Lodi, Italy. ${ }^{4}$ Parco Tecnologico Padano, Via Einstein, 26900 Lodi, Italy. ${ }^{5}$ Scuola di Dottorato in Medicina
Molecolare e Traslazionale, Università di Milano, Segrate, Milan 20009, Italy. "Istituto Nazionale di Genetica Molecolare "Romeo ed Enrica Invernizzi", Via Francesco Sforza 35, 20122 Milan, Italy.

Received: 27 April 2016 Accepted: 12 January 2017

Published online: 19 January 2017

\section{References}

1. Halasa T, Huijps $K$, Østerås $O$, Hogeveen $H$. Economic effects of bovine mastitis and mastitis management: a review. Vet Q. 2007;29:18-31.

2. Bannerman DD, Paape MJ, Lee JW, Zhao X, Hope JC, Rainard P. Escherichia coli and Staphylococcus aureus elicit differential innate immune responses following intramammary infection. Clin Diagn Lab Immunol. 2004;11:463-72.

3. Zecconi A, Binda E, Borromeo V, Piccinini R. Relationship between some Staphylococcus aureus pathogenic factors and growth rates and somatic cell counts. J Dairy Res. 2005;72:203-8.

4. Cremonesi P, Pozzi F, Raschetti M, Bignoli G, Capra E, Graber HU, Vezzoli F, Piccinini R, Bertasi B, Biffani S, Castiglioni B, Luini M. Genomic characteristics of Staphylococcus aureus strains associated with high within-herd prevalence of intramammary infections in dairy cows. J Dairy Sci. 2015;98(10):6828-38.

5. Fournier C, Kuhnert P, Frey J, Miserez R, Kirchhofer M, Kaufmann T, Steiner A, Graber HU. Bovine Staphylococcus aureus: association of virulence genes, genotypes and clinical outcome. Res Vet Sci. 2008;85:439-48.

6. Graber HU, Naskova J, Studer E, Kaufmann T, Kirchhofer M, Brechbühl M, Schaeren W, Steiner A, Fournier C. Mastitis-related subtypes of bovine Staphylococcus aureus are characterized by different clinical properties. J Dairy Sci. 2009;92:1442-51.

7. Cosandey A, Boss R, Luini M, Artursson K, Bardiau M, Breitenwieser F, Hehenberger E, Lam T, Mansfeld M, Michel A, Mösslacher G, Naskova J, Nelson S, Podpečan O, Raemy A, Ryan E, Salat O, Zangerl P, Steiner A, Graber $\mathrm{HU}$. Staphylococcus aureus genotype B and other genotypes isolated from cow milk in European countries. J Dairy Sci. 2016;99:529-40.

8. Boss R, Cosandey A, Luini M, Artursson K, Bardiau M, Breitenwieser F, Hehenberger E, Lam T, Mansfeld M, Michel A, Mösslacher G, Naskova J, Nelson S, Podpečan O, Raemy A, Ryan E, Salat O, Zangerl P, Steiner A, Graber HU. Bovine Staphylococcus aureus: Subtyping, evolution, and zoonotic transfer. J Dairy Sci. 2016:99:515-28.

9. Sakwinska O, Giddey M, Moreillon M, Morisset D, Waldvogel A, Moreillon P. Staphylococcus aureus host range and human-bovine host shift. Appl Environ Microbiol. 2011;77:5908-15.

10. Kozytska S, Stauss D, Pawlik MC, Hensen S, Eckart M, Ziebuhr W, Witte W, Ohlsen K. Identification of specific genes in Staphylococcus aureus strains associated with bovine mastitis. Vet Microbiol. 2010;145:360-5.

11. van Cleef BA, Monnet DL, Voss A, Krziwanek K, Allerberger F, Struelens M, Zemlickova H, Skov RL, Vuopio-Varkila J, Cuny C, Friedrich AW, Spiliopoulou I, Paszti J, Hardardottir H, Rossney A, Pan A, Pantosti A, Borg M, Grundmann H, Mueller-Premru M, Olsson-Liljequist B, Widmer A, Harbarth S, Schweiger A, Unal A, Kluytmans JA. Livestock associated methicillin-resistant Staphylococcus aureus in humans, Europe. Emerg Infect Dis. 2011;17:502-5.

12. Hendriksen RS, Mevius DJ, Schroeter A, Teale C, Meunier D, Butaye P, Franco A, Utinane A, Amado A, Moreno M, Greko C, Stark K, Berghold C, Myllyniemi AL, Wasyl D, Sunde M, Aarestrup FM. Prevalence of antimicrobial resistance among bacterial pathogens isolated from cattle in different European countries: 2002-2004. Acta Vet Scand. 2008;50:28.

13. Luini M, Cremonesi P, Magro G, Bianchini V, Minozzi G, Castiglioni B, Piccinini R. Methicillin-resistant Staphylococcus aureus (MRSA) is associated with low withinherd prevalence of intra-mammary infections in dairy cows: Genotyping of isolates. Vet Microbiol. 2015;178:270-4.

14. Spohr M, Rau J, Friedrich A, Klittich G, Fetsch A, Guerra B, Hammerl JA Tenhagen BA. Methicillin-resistant Staphylococcus aureus (MRSA) in three dairy herds in southwest Germany. Zoonoses Public Health. 2011;58:252-61.

15. Vanderhaeghen W, Cerpentier T, Adriaensen C, Vicca J, Hermans K, Butaye P. Methicillin-resistant Staphylococcus aureus (MRSA) ST398 associated with clinical and subclinical mastitis in Belgian cows. Vet Microbiol. 2010;144:166-71.

16. Harris SR, Cartwright EJ, Török ME, Holden MT, Brown NM, Ogilvy-Stuart AL, Ellington MJ, Quail MA, Bentley SD, Parkhill J, Peacock SJ. Whole-genome sequencing for analysis of an outbreak of meticillin-resistant Staphylococcus aureus: a descriptive study. Lancet Infect Dis. 2013;13:130-6.

17. Sherry NL, Porter JL, Seemann T, Watkins A, Stinear TP, Howden BP. Outbreak investigation using high-throughput genome sequencing within a diagnostic microbiology laboratory. J Clin Microbiol. 2013;51:1396-401. 
18. Young BC, Golubchik T, Batty EM, Fung R, Larner-Svensson H, Votintseva AA, Miller RR, Godwin H, Knox K, Everitt RG, lqbal Z, Rimmer AJ, Cule M, Ip CL, Didelot X, Harding RM, Donnelly P, Peto TE, Crook DW, Bowden R, Wilson DJ. Evolutionary dynamics of Staphylococcus aureus during progression from carriage to disease. Proc Natl Acad Sci. 2012;109:4550-5.

19. Chua KY, Seemann T, Harrison PF, Monagle S, Korman TM, Johnson PD, Coombs GW, Howden BO, Davies JK, Howden BP, Stinear TP. The dominant Australian community-acquired methicillin-resistant Staphylococcus aureus clone ST93-IV [2B] is highly virulent and genetically distinct. PLoS One. 2011;6:e25887.

20. Castillo-Ramírez S, Corander J, Marttinen P, Aldeljawi M, Hanage WP, Westh $H_{\text {, }}$ Boye K, Gulay Z, Bentley SD, Parkhill J, Holden MT, Feil EJ. Phylogeographic variation in recombination rates within a global clone of methicillin resistant Staphylococcus aureus. Genome Biol. 2012;13:R126.

21. Holden MT, Hsu LY, Kurt K, Weinert LA, Mather AE, Harris SR, Strommenger B, Layer F, Witte W, de Lencastre H, Skov R, Westh H, Zemlicková H, Coombs G, Kearns AM, Hill RL, Edgeworth J, Gould I, Gant V, Cooke J, Edwards GF, McAdam PR, Templeton KE, McCann A, Zhou Z, Castillo-Ramírez S, Feil EJ, Hudson LO, Enright MC, Balloux F, Aanensen DM, Spratt BG, Fitzgerald JR, Parkhill J, Achtman M, Bentley SD, Nübel U. A genomic portrait of the emergence, evolution, and global spread of a methicillin-resistant Staphylococcus aureus pandemic. Genome Res. 2013;23:653-64.

22. Le Maréchal C, Seyffert N, Jardin J, Hernandez D, Jan G, Rault L, Azevedo V François P, Schrenzel J, van de Guchte M, Even S, Berkova N, Thiéry R, Fitzgerald $J R$, Vautor E, Le Loir Y. Molecular basis of virulence in Staphylococcus aureus mastitis. PLoS One. 2011;6:e27354.

23. Peton V, Bouchard DS, Almeida S, Rault L, Falentin H, Jardin J, Jan G, Hernandez D, François P, Schrenzel J, Azevedo V, Miyoshi A, Berkova N, Even S, Le Loir Y. Fine-tuned characterization of Staphylococcus aureus Newbould 305, a strain associated with mild and chronic mastitis in bovines. Vet Res. 2014;45:106.

24. O'Neill AJ, Lindsay JA, Gould K, Hinds J, Chopra I. Transcriptional signature following inhibition of early-stage cell wall biosynthesis in Staphylococcus aureus. Antimicrob Agents Chemother. 2009;53:1701-4

25. Xu HH, Trawick JD, Haselbeck RJ, Forsyth RA, Yamamoto RT, Archer R, Patterson J, Allen M, Froelich JM, Taylor I, Nakaji D, Maile R, Kedar GC, Pilcher M, BrownDriver V, McCarthy M, Files A, Robbins D, King P, Sillaots S, Malone C, Zamudio CS, Roemer T, Wang L, Youngman PJ, Wall D. Staphylococcus aureus Target Array: comprehensive differential essential gene expression as a mechanistic tool to profile antibacterials. Antimicrob Agents Chemother. 2010;54:3659-70.

26. Morrison JM, Miller EW, Benson MA, Alonzo 3rd F, Yoong P, Torres VJ, Hinrichs SH, Dunman PM. Characterization of SSR42, a novel virulence factor regulatory RNA that contributes to the pathogenesis of a Staphylococcus aureus USA300 representative. J Bacteriol. 2012;194:2924-38.

27. Osmundson J, Dewell S, Darst SA. RNA-Seq reveals differential gene expression in Staphylococcus aureus with single-nucleotide resolution. PLoS One. 2013;8:e76572

28. Qin N, Tan X, Jiao Y, Liu L, Zhao W, Yang S, Jia A. RNA-Seq-based transcriptome analysis of methicillin-resistant Staphylococcus aureus biofilm inhibition by ursolic acid and resveratrol. Sci Rep. 2014;4:5467

29. Beaume M, Hernandez D, Farinelli L, Deluen C, Linder P, Gaspin C, Romby P, Schrenzel J, Francois P. Cartography of Methicillin-Resistant Staph. aureus Transcripts: Detection, Orientation and Temporal Expression during Growth Phase and Stress Conditions. PLoS One. 2010;5:e10725.

30. Howden BP, Beaume M, Harrison PF, Hernandez D, Schrenzel J, Seemann T, Francois P, Stinear TP. Analysis of the small RNA transcriptional response in multidrug-resistant Staphylococcus aureus after antimicrobial exposure. Antimicrob Agents Chemother. 2013;7:3864-74.

31. Enright MC, Day NP, Davies CE, Peacock SJ, Spratt BG. Multilocus sequence typing for characterization of methicillin-resistant and methicillin-susceptible clones of Staphylococcus aureus. J Clin Microbiol. 2000;38:1008-15.

32. Cremonesi P, Castiglioni B, Malferrari G, Biunno I, Vimercati C, Moroni P, Morandi S, Luzzana M. Technical note: Improved method for rapid DNA extraction of mastitis pathogens directly from milk. J Dairy Sci. 2006;89:163-9.

33. Bolger M, Lohse M, Usadel B. Trimmomatic: A flexible trimmer for Illumina sequence data. Bioinformatics. 2014;30:2114-20.

34. Bankevich A, Nurk S, Antipov D, Gurevich AA, Dvorkin M, Kulikov AS, Lesin VM, Nikolenko SI, Pham S, Prjibelski AD, Pyshkin AV, Sirotkin AV, Vyahhi N, Tesler G, Alekseyev MA, Pevzner PA. SPAdes: a new genome assembly algorithm and its applications to single-cell sequencing. J Comput Biol. 2012;19:455-77.
35. Lin SH, Liao YC. CISA: contig integrator for sequence assembly of bacterial genomes. PloS One. 2013;8:e60843.

36. Aziz RK, BartelsD BAA, DeJongh M, Disz T, Edwards RA, Zagnitko O. The RAST Server: rapid annotations using subsystems technology. BMC Genomics. 2008;9:75.

37. Sonnhammer EL, Östlund G. InParanoid 8: orthology analysis between 273 proteomes, mostly eukaryotic. Nucleic Acids Res. 2015;43:D234-9.

38. Agren J, Sundström A, Håfström T, Segerman B. Gegenees: fragmented alignment of multiple genomes for determining phylogenomic distances and genetic signatures unique for specified target groups. PLoS One. 2012; 7:e39107.

39. Kloepper TH, Huson DH. Drawing explicit phylogenetic networks and their integration into SplitsTree. BMC Evol Biol. 2008;8:22.

40. Alikhan NF, Petty NK, Ben Zakour NL, Beatson SA. BLAST Ring Image Generator (BRIG): simple prokaryote genome comparisons. BMC Genomics. 2011;12:402.

41. Li H, Durbin R. Fast and accurate short read alignment with Burrows-Wheeler Transform. Bioinformatics. 2009:25:1754-60.

42. Peano C, Pietrelli A, Consolandi C, Rossi E, Petiti L, Tagliabue L, De Bellis G, Landini P. An efficient rRNA removal method for RNA sequencing in GC-rich bacteria. Microb Inform Exp. 2013;3:1.

43. Peano C, Chiaramonte F, Motta S, Pietrelli A, Jaillon S, Rossi E, Consolandi C, Champion OL, Michell SL, Freddi L, Falciola L, Basilico F, Garlanda C, Mauri P, De Bellis $G$, Landini P. Gene and protein expression in response to different growth temperatures and oxygen availability in Burkholderia thailandensis. PLoS One. 2014;9:e93009.

44. Anders S, Huber W. Differential expression analysis for sequence count data. Genome Biol. 2010;11:R10.

45. Tatusov RL, Galperin MY, Natale DA, Koonin EV. The COG database: a tool for genome-scale analysis of protein functions and evolution. Nucleic Acids Res. 2000;28:33-6.

46. Robinson JT, Thorvaldsdóttir H, Winckler W, Guttman M, Lander ES, Getz G, Mesirov JP. Integrative genomics viewer. Nat Biotechnol. 2011;29:24-6.

47. Theis T, Skurray RA, Brown MH. Identification of suitable internal controls to study expression of a Staphylococcus aureus multidrug resistance system by quantitative real-time PCR. J Microbiol Methods. 2007;70:355-62.

48. Moriya Y, Itoh M, Okuda S, Yoshizawa AC, Kanehisa M. KAAS: an automatic genome annotation and pathway reconstruction server. Nucleic Acids Res. 2007:35:W182-5.

49. Schijffelen MJ, Boel CH, van Strijp JA, Fluit AC. Whole genome analysis of a livestock-associated methicillin-resistant Staphylococcus aureus ST398 isolate from a case of human endocarditis. BMC Genomics. 2010;11:376.

50. Highlander SK, Hultén KG, Qin X, Jiang H, Yerrapragada S, Mason Jr EO, Shang Y, Williams TM, Fortunov RM, Liu Y, Igboeli O, Petrosino J, Tirumalai M, Uzman A, Fox GE, Cardenas AM, Muzny DM, Hemphill L, Ding Y, Dugan S, Blyth PR, Buhay CJ, Dinh HH, Hawes AC, Holder M, Kovar CL, Lee SL, Liu W, Nazareth LV, Wang Q, Zhou J, Kaplan SL, Weinstock GM. Subtle genetic changes enhance virulence of methicillin resistant and sensitive Staphylococcus aureus. BMC Microbiol. 2007;7:99.

51. Balaban N, Goldkorn T, Gov Y, Hirshberg M, Koyfman N, Matthews HR, Nhan RT, Singh B, Uziel O. Regulation of Staphylococcus aureus pathogenesis via target of RNAlll-activating Protein (TRAP). J Biol Chem. 2001;276:2658-67

52. Korem M, Gov Y, Kiran MD, Balaban N. Transcriptional Profiling of Target of RNAll-Activating Protein, a Master Regulator of Staphylococcal Virulence. Infect Immun. 2005;73:6220-8.

53. Foster TJ, Geoghegan JA, Ganesh VK, Höök M. Adhesion, invasion and evasion: the many functions of the surface proteins of Staphylococcus aureus. Nat Rev Microbiol. 2014;12:49-62.

54. Peacock SJ, Foster TJ, Cameron BJ, Berendt AR. Bacterial fibronectin binding proteins and endothelial cell surface fibronectin mediate adherence of Staphylococcus aureus to resting human endothelial cells. Microbiology. 1999;145:3477-86

55. Sinha B, Francois PP, Nusse O, Foti M, Hartford OM, Vaudaux P, Foster TJ, Lew DP, Herrmann M, Krause KH. Fibronectin-binding protein acts as Staphylococcus aureus invasin via fibronectin bridging to integrin alpha5beta1. Cell Microbiol. 1999:1:101-17.

56. McCarthy AJ, Lindsay JA. Genetic variation in Staphylococcus aureus surface and immune evasion genes is lineage associated: implications for vaccine design and host-pathogen interactions. BMC Microbiol. 2010;10:173.

57. Burke FM, McCormack N, Rindi S, Speziale P, Foster TJ. Fibronectin-binding protein B variation in Staphylococcus aureus. BMC Microbiol. 2010;10:160. 
58. NíEidhin D, Perkins S, Francois P, Vaudaux P, Höök M, Foster TJ. Clumping factor B (ClfB), a new surface-located fibrinogen-binding adhesin of Staphylococcus aureus. Mol Microbiol. 1998;30:245-57.

59. Josefsson E, McCrea KW, Eidhin DN, O'Connell D, Cox J, Hook M, Foster TJ. Three new members of the serine-aspartate repeat protein multigene family of Staphylococcus aureus. Microbiology. 1998;144:3387-95.

60. Sabat A, Krzyszton-Russjan J, Strzalka W, Filipek R, Kosowska K, Hryniewicz W, Travis J, Potempa J. New method for typing Staphylococcus aureus strains: Multiple-locus variable-number tandem repeat analysis of polymorphism and genetic relationships of clinical isolates. J Clin Microbiol. 2003;41:1801-4.

61. Roche FM, Meehan M, Foster TJ. The Staphylococcus aureus surface protein SasG and its homologues promote bacterial adherence to human desquamated nasal epithelial cells. Microbiology. 2003;149:2759-67.

62. Clarke SR, Mohamed R, Bian L, Routh AF, Kokai-Kun JF, Mond JJ, Tarkowski A, Foster SJ. The Staphylococcus aureus surface protein isda mediates resistance to innate defenses of human skin. Cell Host Microbe. 2007;1:199-212.

63. Lee LY, Miyamoto YJ, McIntyre BW, Hook M, McCrea KW, Mc Devitt D, Brown EL. The Staphylococcus aureus Map protein is an immunomodulator that interferes with T cell-mediated responses. J Clin Invest. 2002;1 10:1461-71.

64. Hussain M, von Eiff C, Sinha B, Joost I, Herrmann M, Peters G, Becker K. eap Gene as novel target for specific identification of Staphylococcus aureus. J Clin Microbiol. 2008:46:470-6.

65. Joost I, Blass D, Burian M, Goerke C, Wolz C, von Müller L, Becker K, Preissner K, Herrmann M, Bischoff $M$. Transcription analysis of the extracellular adherence protein from Staphylococcus aureus in authentic human infection and in vitro. J Infect Dis. 2009:199:1471-8.

66. Rooijakkers SH, Ruyken M, van Roon J, van Kessel KP, van Strijp JA, van Wamel WJ. Early expression of SCIN and CHIPS drives instant immune evasion by Staphylococcus aureus. Cell Microbiol. 2006;8:1282-93.

\section{Submit your next manuscript to BioMed Central and we will help you at every step:}

- We accept pre-submission inquiries

- Our selector tool helps you to find the most relevant journal

- We provide round the clock customer support

- Convenient online submission

- Thorough peer review

- Inclusion in PubMed and all major indexing services

- Maximum visibility for your research

Submit your manuscript at www.biomedcentral.com/submit

) Biomed Central 